\title{
Contacts between poultry farms, their spatial dimension and their relevance for avian influenza preparedness
}

\author{
Lena Fiebig ${ }^{1}$, Timo Smieszek ${ }^{2}$, Jennifer Saurina ${ }^{1,3}$, Jan Hattendorf ${ }^{1}$, Jakob Zinsstag ${ }^{1}$ \\ ${ }^{1}$ Swiss Tropical Institute, Department of Public Health and Epidemiology, P.O. Box, CH-4002 Basel, \\ Switzerland; ${ }^{2}$ ETH Zurich, Institute for Environmental Decisions, CHN J 70.1, Universitaetsstrasse 22, \\ CH-8092 Zurich, Switzerland; ${ }^{3}$ current affiliation: Swiss Federal Office of Public Health, Berne, \\ Schwarztorstrasse 96, CH-3007 Berne, Switzerland
}

\begin{abstract}
Ongoing economic losses by and exposure of humans to highly pathogenic avian influenza (HPAI) in poultry flocks across Asia and parts of Africa and Europe motivate also outbreak-free countries such as Switzerland to invest in preparedness planning. Country-specific population data on between-farm contacts are required to anticipate probable patterns of pathogen spread. Information is scarce; in particular on how strongly small, non-commercial poultry farms are involved in between-farm contacts. We aimed to identify between-farm contacts of interest for HPAI spread at both commercial and non-commercial farms in a non-outbreak situation: whether or not commercial and non-commercial farms were involved in poultry and person movements and shared resources by company integration. Focus was on poultry movements for the purpose of purchase, sale and poultry show visits, their spatial dimension, their frequencies and the farm types they connected. Of the total 49,437 recorded poultry farms in Switzerland, 95\% had less than 500 birds. The farm number resulted in densities of up to 8 poultry farms per $\mathrm{km}^{2}$ and a median number of 47 neighbour farms within a $3 \mathrm{~km}$ radius around the farms. Person movements and shared resources were identified in $78 \%$ of the surveyed farms $(93 \%$ among commercials, $67 \%$ among non-commercials). Poultry trading movements over extensive spatial ranges were stated at $65 \%$ (79\% among commercials, $55 \%$ among non-commercials). Movement frequencies depended on farm specialization and were higher for commercial than for non-commercial farms except for poultry show visits. Estimates however for the entire population revealed 3.5 times higher chances of a poultry purchase, and 14.6 times higher chances of exhibiting birds at poultry shows occurring in a given time by a farm smaller than 500 birds (non-commercial farm) than by a larger (commercial) farm. These findings indicate that both commercial and non-commercial farms are involved in neighbourhood and remote between-farm contacts relevant to HPAI spread. It is necessary to include all poultry farms, irrespective of their size and purpose in both livestock registration and disease surveillance systems, as well as in transmission models for poultry and zoonotic diseases.
\end{abstract}

Keywords: highly pathogenic avian influenza (HPAI), between-farm contacts, poultry movement distances, non-commercial poultry farms, Switzerland.

\section{Introduction}

Highly pathogenic avian influenza (HPAI) has been noted for decades as an animal disease with

Corresponding author:

Lena Fiebig

Department of Public Health and Epidemiology

Swiss Tropical Institute, University of Basel

P.O. Box, CH-4002, Basel, Switzerland

Tel. +41 61284 8226; Fax +41612848105

E-mail: Lena.Fiebig@unibas.ch high economic impact. Although well documented and reported, HPAI received little public attention until 1997 when, for the first time, human infections due to the H5N1 HPAI virus strain were confirmed (de Jong et al., 1997) and caused 262 confirmed fatal human cases to date (WHO, 2009). Since December 2003, HPAI viruses, mainly H5N1, have reached poultry populations across Asia and parts of Africa and Europe causing high economic losses (Koppinen, 2005; Webster et al., 2006; Dent et al., 2008; Fasina et al., 2008). Switzerland has been free 
from HPAI in domestic poultry since the 1930s but in early 2006, 34 cases of H5N1 HPAI-infected dead water fowl were identified (Hofmann et al., 2008). Both wild birds (Kilpatrick et al., 2006) and the import of poultry and poultry products represent a certain risk of HPAI virus introduction into the Swiss poultry sector (Hauser et al., 2006b).

HPAI virus transmission to susceptible birds occurs by direct contact with excretions and secretions from infected birds and indirectly via contaminated water, feed and equipment used on a farm. Between-farm transmission can occur through direct bird-to-bird contact when subclinically infected poultry is traded or exhibited at poultry shows. Other animals such as wild birds, martens, or domestic cats are known to potentially act as vectors (OIE, 2002; Normile, 2005; Klopfleisch et al., 2007). People can contribute to virus spread by introducing contaminated fomites into a susceptible flock. Such between-farm contacts are also depending on the organization of the local structure of poultry industry (Capua et al., 2002b).

It is known from post-outbreak investigations that such potentially contagious contacts, in particular livestock movements amongst farms, strongly influence the course of epidemics (Shirley and Rushton, 2005). The distribution of number of contacts (degree distribution) among the members of a population (here poultry farms) was shown to be relevant for identifying members with high probabilities of being infected early in a course of epidemic because of having many incoming contacts. Members having many outgoing contacts were causing high numbers of secondary cases (Woolhouse et al., 1997; Bell et al., 1999; Bansal et al., 2007). Furthermore, it was shown that high dispersions of degree distributions lowered the epidemic threshold, and thus were an important factor to consider when predicting epidemic dynamics (Hethcote and Yorke, 1984; Anderson and May, 1991; Pastor-Satorras and Vespignani, 2001; Duerr et al., 2007). Clustering, describing how many of a member's contact partners have contact amongst one another, and other structural properties such as the stability of contacts further influence the spread of disease. To assume that all members have equal numbers of contacts and that they randomly chose contact partners, changing them continuously as is often done in transmission models, is known to overestimate the size of an outbreak for many infectious diseases (Zaric, 2002; Lyytikäinen et al., 2009; Smieszek et al., 2009).

Only rarely detailed contact information in its spatial context has been systematically integrated in models for HPAI transmission and used for the planning of preparedness and control strategies. Boender et al. (2007) performed a spatial analysis of the HPAI outbreak that occurred in 2003 in the Netherlands. They modeled HPAI transmission from infected to uninfected farms as a function of inter-farm distance and farm density. Resulting risk maps help to define areas where preemptive culling is advisable. Truscott et al. (2007) showed that transmission models taking both density-dependent spatial transmission and periodic network contacts into account were particularly suitable to reflect HPAI spread within the Great Britain poultry flock. Other countries, especially those not yet experiencing HPAI outbreaks can draw on these findings in their own preparedness planning.

Country-specific information on the spatial distribution, structural composition and the connectedness of the poultry sector is required to develop transmission models properly. In particular it has to be clarified to what extent non-commercial poultry farms should be considered. Their role in betweenfarm transmission is controversial. Often non-commercial farms were defined by small flock sizes and were assumed to have small poultry movement distances. However, Garber et al. (2007) investigated destination locations for "birds sold or given away" by non-commercial farms in the USA and found movements beyond the State and beyond the USA borders. Capua et al. (2002a) suggested defining non-commercial backyard poultry farms not only by small flock size but primarily by the absence of functional connection to commercial poultry production systems. Such definition would imply that 
specific information on the interconnectedness of the poultry sector is available. Boender et al. (2007) considered only commercial flocks in their model. In Great Britain, only farms with 50 or more birds kept have to be registered, and are thus included in models. Distant contacts were only taken into account for farms keeping 500 or more birds (Truscott et al., 2007) or 1,000 and more birds (Dent et al., 2008). This makes it difficult to judge the actual role of non-commercial poultry husbandries in between-farm transmission scenarios.

This study was aimed to identify between-farm contacts of interest for HPAI spread at both commercial and non-commercial farms in a non-outbreak situation. We took advantage of available data in Switzerland where registration of poultry farms irrespective of size and purpose has been introduced in 2005 on a communal and cantonal level (Schweizerischer Bundesrat, 2005). We georeferenced the locations of poultry farms to understand where occasional between-farm contacts within a neighbourhood were most probable. We then identified in a cross-sectional study whether commercial and non-commercial farms were involved in person movements, such as employees shared by two farms, and shared resources by company integration (affiliation to poultry marketing organizations). Of particular interest were poultry movements for the purpose of purchase, sale and poultry show visits, their spatial dimensions, their frequencies and the farm types they connected.

This was to inform the discussion on whether at all, and under what circumstances poultry farms, and non-commercial farms in particular, play a role in the sector's connectedness and how they should be considered in the HPAI surveillance system and in pertinent transmission models.

\section{Material and methods}

\section{Study population and density of poultry farms}

The population investigated in this study are the poultry farms of Switzerland. By "poultry farm" we understand all sites where one or more domestic chicken (Gallus gallus domesticus), turkey (Meleagris gallopavo), duck (Anas platyrhynchos domesticus or Cairina moschata), goose (Anser anser), quail (Coturnix coturnix), guinea fowl (Numida meleagris), peafowl (Pavo cristatus), ostrich (Struthio camelus) and/or pigeon (Columba livia) are kept.

We established a single list of all recorded poultry keepers and farms (data from 2005 to 2007) in Switzerland out of 23 registers maintained by the 26 Swiss cantons (some cantons cooperate), and the federal livestock register database "Agrar information system (AGIS)" from 2005 (Bundesamt für Landwirtschaft, 2007). The AGIS contains only farms receiving direct government subsidy. The cantons recorded either all their poultry farms or only those not included in AGIS. Therefore data from all sources had to be merged and duplicates to be eliminated electronically privileging the more recent cantonal records. This lead to a single list subsequently called "census" containing a total of 49,437 countrywide identified poultry keepers. Captured attributes included farm address and total number of birds kept. Further farm details were provided in the original registers, however not in a standardized way. Manual checks revealed similar entries of farms under different names. Thus, the census might still contain some duplicates.

The address data from the census were georeferenced and read into a base map from Swisstopo $2008^{\circledR}$. An accuracy of exact localization was reached for $78 \%$ of the farms. For $6 \%$ and for $15 \%$ only precision on the street level and on the postal code level could be achieved, respectively. The census was used to investigate the density distributions of poultry farms and birds kept for the entire country and to depict them in density maps.

\section{Survey design}

The investigation of the between-farm contacts and their determinants followed a mixed methods research design. First a quantitative cross-sectional 
study among poultry keepers was conducted. In addition five experts from companies integrating commercial poultry farms (poultry and egg marketing organizations) were interviewed (qualitative part).

\section{Cross-sectional study among poultry keepers}

The census was used as sampling frame of which a random sample of 3,978 poultry keepers was drawn. The poultry keepers' probability of being selected for the cross-sectional study was proportional to the square root of the number of birds kept on their farm (farm size), to ensure a sufficient number of the less numerous larger poultry farms.

A mail-out/mail-back survey among the 3,978 selected poultry keepers was conducted between August and December 2007. As survey instrument a structured questionnaire was developed in the German language and translated into French and Italian; national languages of Switzerland. Topics covered between-farm contacts, a self-assessment of the farm type by the respondent, a section on disease awareness, and one on wild bird observations in the poultry free-range area if existing. The two latter topics are presented in another manuscript (Saurina et al., in press) and unpublished data.

\section{Defining relevant contacts}

Between-farm contacts potentially relevant for HPAI transmission were identified based on available literature (OIE, 2002; Thomas et al., 2005; WHO, 2006; DEFRA, 2007; Grabkowsky, 2007) and based on consultation with poultry experts. The investigated contact relations included farm neighbourhood and neighbourhood-related contacts. Farm neighbourhoods are commonly considered to allow for casual contacts between the poultry keepers and overlapping movement ranges of potential vectors such as sparrows and freely moving domestic animals such as cats being potential vectors for HPAI viruses (Reed et al., 2003; Kuiken et al., 2004). This is reflected in the implementation of control and surveillance zones with $3 \mathrm{~km}$ and $10 \mathrm{~km}$ radii as a HPAI control measurement regulated in the Animal Health Act (Bundesversammlung der Schweizerischen Eidgenossenschaft, 2006) and $1 \mathrm{~km}$ bands for risk zones in other appraisals (Hauser et al., 2006a). Therefore, the number of the participants' neighbour farms within all 1,3 and $10 \mathrm{~km}$ radii was based on the addresses given in the poultry farm census. Contacts surpassing a $10 \mathrm{~km}$ radius were defined as remote contacts.

Investigated contact relations beyond neighbourhoods included human movements, shared resources and poultry movements (Table 1). Poultry movements for the purpose of "purchase" and "sale" had one direction, those for "exhibiting birds at poultry shows" were bidirectional. The questionnaire allowed specifying of up to six different contact partners for each purchase, sale and show visits. Date (month/year), site (postal code) and types of contacts (hatchery, other farm or abattoir/butcher) or name of poultry show were inquired. The frequency of poultry trade and show visits was captured in "x times per year" and "less than once a year" which was coded as 0.5 times per year in the analyses. The term "poultry" included here live birds of the species described above, one-day chicks and also hatching eggs.

\section{Data processing and analysis}

Data of the returned and completed questionnaires were double-entered into a database, compared and cleaned. Presented analyses rely on data of $1,317(33 \%)$ questionnaires that contained valid contact information. Spatial data were collected for all poultry movements, "show visits" and "coworking" in the form of the postal code of the contact partner or event. Postal codes were geo-referenced. Maximum air-line distances in $\mathrm{km}$ between respondents and contacts were calculated for each contact relation if the postal code was given. Map presentations were completed using the maptools and spatstat libraries in $\mathrm{R}$ and base maps from Swisstopo $2008^{\circledR}$.

Two participant groups were formed based on the 
respondents' self-description in the questionnaire: "commercial" and "non-commercial" poultry farms. Further information on these groups is provided in Box 1.

Multinomial models with poultry movement distances as an outcome were used to investigate the following explanatory variables: number of birds kept (farm size), the respondent's farm type, and flock composition. Estimates and confidence intervals for the poultry movement frequency of the entire poultry sector were constructed using Bootstrap resampling with 2,000 replications.

\section{Interviews with experts from poultry industry}

For the purpose of data triangulation and complementary information on between-farm contacts, interviews with experts from the poultry industry were conducted in addition to the survey. Five companies integrating commercial poultry farms in Switzerland were selected for interviews. The selection was based on whether the companies were frequently named by the survey participants and in order to include different areas of the poultry industry, including broiler and egg production. Company

Table 1. Overview on contact relations under study.

\begin{tabular}{|c|c|c|c|}
\hline Contact relation & Vector & Connection through & Source of information \\
\hline \multicolumn{4}{|l|}{ NEIGHBOURHOOD } \\
\hline $\begin{array}{l}\text { Neighbourhood to other poultry } \\
\text { farms within } 1,3 \text { and } 10 \mathrm{~km}\end{array}$ & Human and animal vectors & Proximity & Poultry farm census \\
\hline \multicolumn{4}{|c|}{ PERSON MOVEMENTS AND SHARED RESOURCES } \\
\hline Poultry show (visiting only) & Person & Co-attending show & Questionnaire \\
\hline Co-working & Person, equipment & Staff and equipment & Questionnaire/interviews \\
\hline Dead stock collection & Person, equipment & $\begin{array}{l}\text { Co-accessing communal } \\
\text { dead stock collection point }\end{array}$ & Questionnaire/interviews \\
\hline Company integration & Person, equipment & Staff and shared resources & Questionnaire/interviews \\
\hline \multicolumn{4}{|l|}{ POULTRY MOVEMENTS } \\
\hline Poultry purchase & Live birds/hatching eggs & Transport (unidirectional) & Questionnaire/interviews \\
\hline Poultry sale & Live birds/hatching eggs & Transport (unidirectional) & Questionnaire/interviews \\
\hline Poultry show (exhibiting birds) & Live birds & Co-attending show & Questionnaire \\
\hline
\end{tabular}

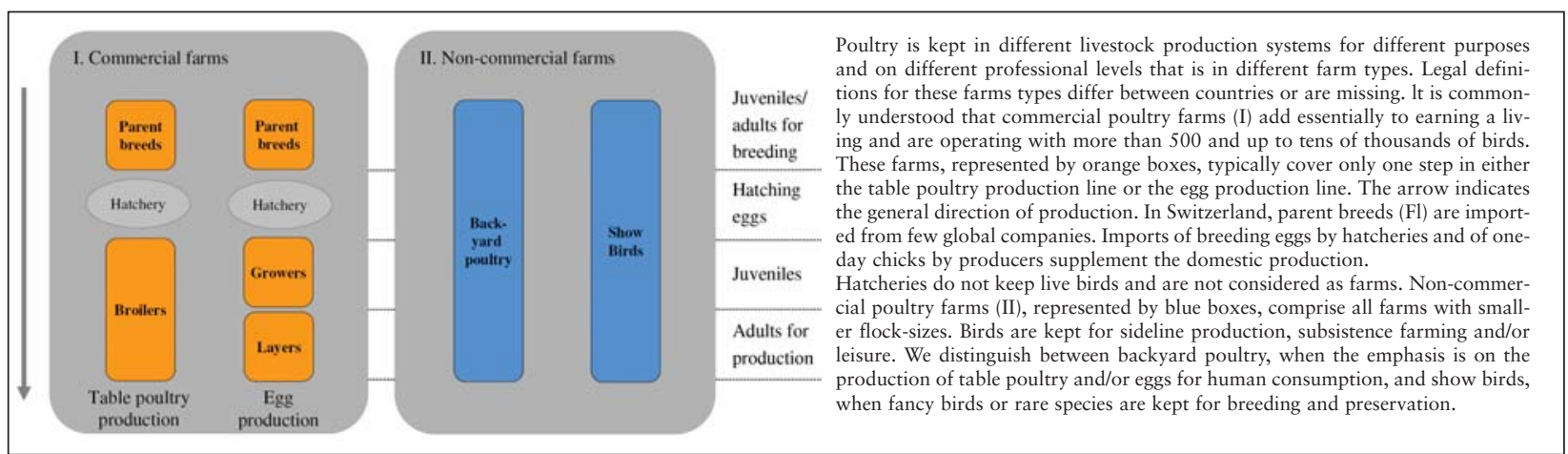

Box 1. Overview of the poultry sector composition. 
I and II, integrating about 400 farms each, covered the entire broiler production line from the hatchery to the abattoir. Companies III to V were involved in egg production; company III contracted about 100 farms with laying hens, company IV regrouped 110 organic farms on different levels. Company V covered around 60 farms levels plus one hatchery. All together the experts represented about one-half of the some 2,000 commercial poultry farms in Switzerland.

Main topics of the interview were between-farm contacts among the company's integrated farms, contacts to outsiders and shared resources. The experts were asked to describe production cycles, numbers, and specifics of their integrated farms. An interview guideline was used to systematically probe on issues not mentioned spontaneously by the experts. Information on poultry trade and shared resources was depicted by expert and interviewer together on paper (mapping tool). Here, different colors were used to draw the studied contact relations (Table 1) amongst the company's farms, and to outsider farms. The interview protocols including notes from experts and the interviewer were transcribed and underwent qualitative content analysis according to Mayring (2003).

\section{Results}

\section{Poultry farm density and neighborhood}

The identified number of poultry farms in Switzerland was 49,437 until May 2007. The largest poultry flock comprised of 47,300 birds and the smallest had 1 bird; $95 \%$ of the farms had less than 500 birds, and $90 \%$ had less than 50 birds. The poultry farm density differed amongst regions. High density areas with more than 8 farms per $\mathrm{km}^{2}$ were presented in purple, areas with moderate farm density in yellow and with very low farm density and no farms in grey. Light areas were congruent with high altitudes in the Alps in southern Switzerland (Fig. 1). The distribution of the number of birds kept per $\mathrm{km}^{2}$ resembled roughly the farm density distribution with low densities in the Alps. Maxima with more than 2,500 birds per $\mathrm{km}^{2}$ were, however, more in the west of the country between Berne and Lausanne reflecting the location of several large commercial farms (Fig. 2). South of Bellinzona farm density was at a maximum, but low numbers of birds were kept per $\mathrm{km}^{2}$ reflecting the sparsity of large commercial farms in that area.
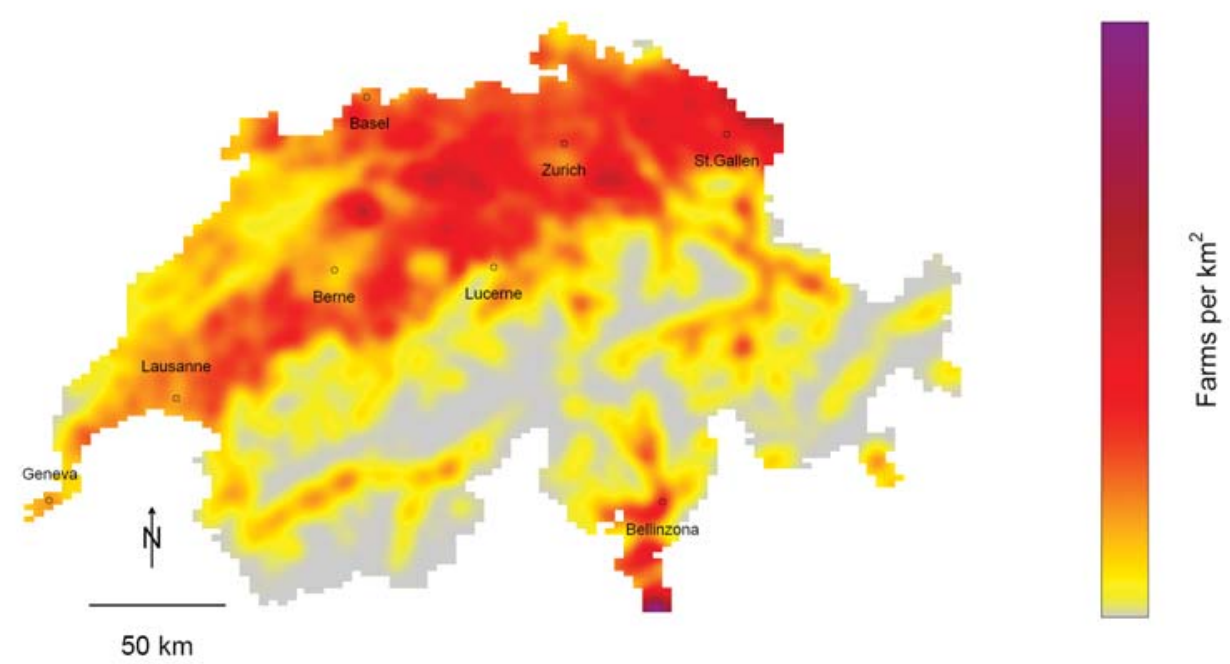

Fig. 1. Density distribution of poultry farms in Switzerland (in farms per $\mathrm{km}^{2}$ ). Locations of important cities of Switzerland are given for orientation. 

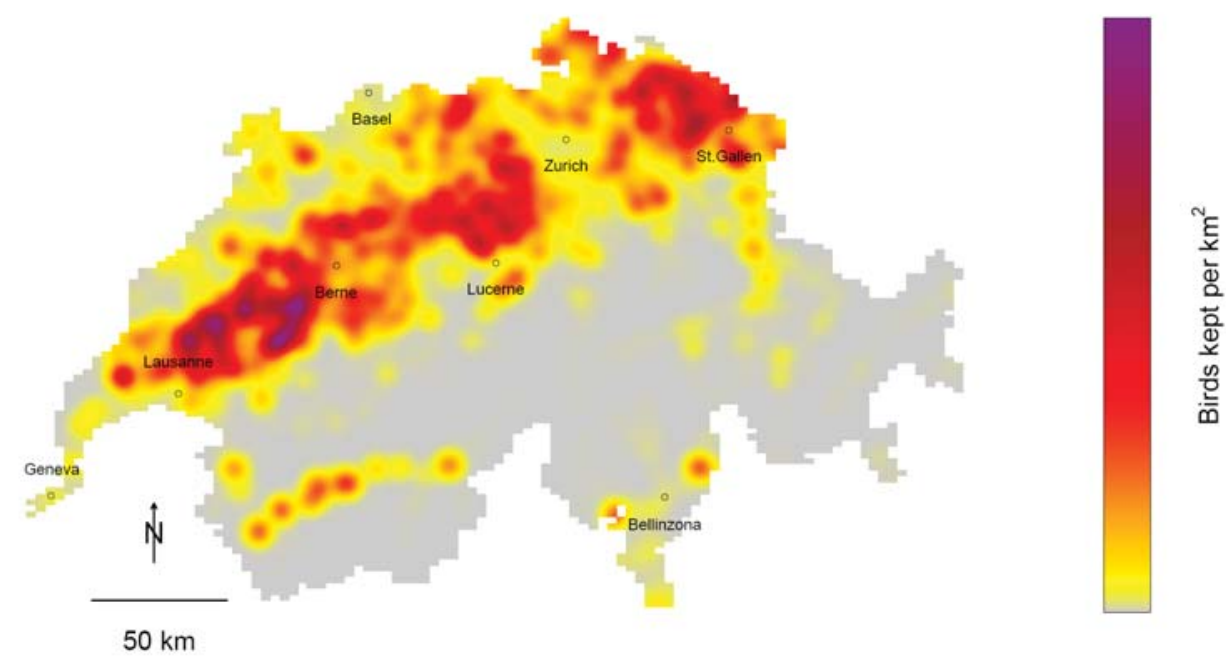

Fig. 2. Density distribution of birds kept in Switzerland (in birds kept per $\mathrm{km}^{2}$ ). Locations of important cities of Switzerland are given for orientation.

In the sample of 1,317 poultry farms, 543 were self-described as commercial farms and 783 as non-commercial farms. Similar group sizes were due to the weighted sampling privileging the less frequent large farms. The median total number of birds kept was 4,500 for commercial farms and 15 for non-commercial farms (Table 2). The threshold between both farm groups was roughly around 500 birds. $97 \%$ of farms had other farms within $1 \mathrm{~km}$ of the farm. Equal median numbers of neighbour farms representing potential contacts were found for both commercial and non-commercial farms with a median of 11 poultry farms within $1 \mathrm{~km}, 47$ within $3 \mathrm{~km}$ and 283 within 10 $\mathrm{km}$ (Table 2).

Potential human and animal vectors (cats) were found on commercial and non-commercial farms. In both groups a median of 3 people were, on average, present on the farm during a normal working day. These persons were mostly described as "staff" at commercial farms and as "residents" and "guests" on non-commercial farms. One or more cats were kept on $65 \%$ of the farms without significant difference between commercial and non-commercial farms (unpublished data).

\section{Person movements and shared resources}

At least one incident of human movement and shared resources was present at $78 \%$ of the participating farms $(93 \%$ for commercial and $67 \%$ for non-commercial farms). "Use of dead stock collection points" was the most frequent response with $75 \%$, "company integration" was stated by $30 \%$, "poultry shows (visiting only)" by $7 \%$ and "coworking" on other farms by $4 \%$ of the respondents. "Use of dead stock collection points", "company integration" and "co-working" on another poultry farm were more common among commercial farms. Non-commercial farms were virtually non-integrated into companies and visited more often poultry shows (Table 3). Median distances were available for "poultry shows (visiting only)" and "co-working". Visited poultry shows were in a median distance of $12 \mathrm{~km}$ from the farm, with $27 \mathrm{~km}$ for the commercial and $8 \mathrm{~km}$ for non-commercial farms. This difference was explained by the commercial farm group mostly indicating visits to national agricultural expositions, and the non-commercial group mostly indicating visits to local shows and markets. "Co-working" on other farm was mainly indicated 
Table 2. Farm specifics and neighbourhood of the commercial and non-commercial farm group and data extrapolation to the entire Swiss poultry sector.

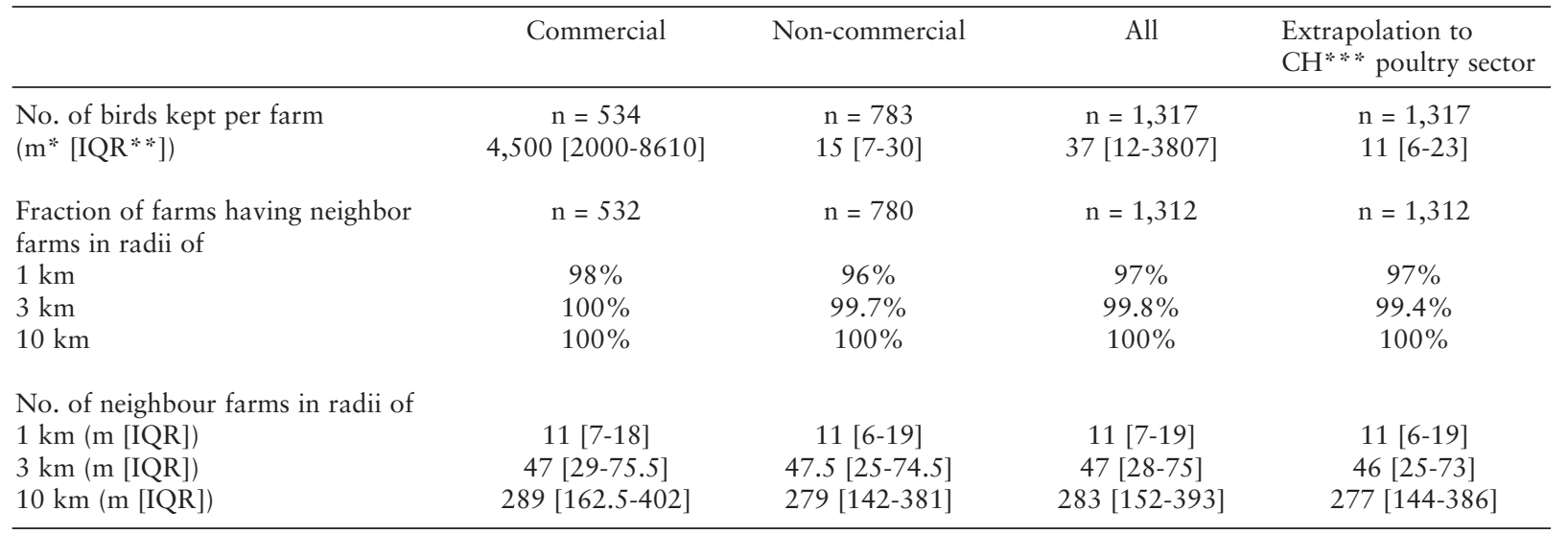

$* \mathrm{~m}=$ median; $*$ IQR $=$ inter-quartile range; $* * \mathrm{CH}=$ Switzerland

Table 3. Prevalence of contact relations under study among the commercial and non-commercial farm group and data extrapolation to the entire Swiss poultry sector.

\begin{tabular}{|c|c|c|c|c|}
\hline & Commercial & Non-commercial & All & $\begin{array}{l}\text { Extrapolation to } \\
\mathrm{CH}^{* * *} \text { poultry sector }\end{array}$ \\
\hline Poultry show (visiting only) & $\begin{array}{c}\mathrm{n}=518 \\
7 \%\end{array}$ & $\begin{array}{c}\mathrm{n}=754 \\
9 \%\end{array}$ & $\begin{array}{c}\mathrm{n}=1,272 \\
9 \%\end{array}$ & $\begin{array}{c}\mathrm{n}=1,272 \\
8 \%\end{array}$ \\
\hline Co-working & $\begin{array}{c}\mathrm{n}=534 \\
10 \%\end{array}$ & $\begin{array}{c}\mathrm{n}=782 \\
1 \%\end{array}$ & $\begin{array}{c}n=1,316 \\
4 \%\end{array}$ & $\begin{array}{c}\mathrm{n}=1,316 \\
1 \%\end{array}$ \\
\hline Dead stock collection points & $\begin{array}{c}\mathrm{n}=533 \\
92 \%\end{array}$ & $\begin{array}{c}\mathrm{n}=782 \\
63 \%\end{array}$ & $\begin{array}{c}\mathrm{n}=1,315 \\
75 \%\end{array}$ & $\begin{array}{c}\mathrm{n}=1,315 \\
62 \%\end{array}$ \\
\hline Company integration & $\begin{array}{c}\mathrm{n}=534 \\
73 \%\end{array}$ & $\begin{array}{c}\mathrm{n}=783 \\
0.3 \%\end{array}$ & $\begin{array}{c}\mathrm{n}=1,317 \\
30 \%\end{array}$ & $\begin{array}{c}\mathrm{n}=1,317 \\
3 \%\end{array}$ \\
\hline $\begin{array}{l}\text { Fraction of farms having one } \\
\text { or more of above incidents }\end{array}$ & $\begin{array}{c}\mathrm{n}=517 \\
93 \%\end{array}$ & $\begin{array}{c}\mathrm{n}=752 \\
67 \%\end{array}$ & $\begin{array}{c}\mathrm{n}=1,269 \\
78 \%\end{array}$ & $\begin{array}{c}\mathrm{n}=1,269 \\
65 \%\end{array}$ \\
\hline \multicolumn{5}{|l|}{ Distance } \\
\hline Poultry show (visiting only) & $\mathrm{n}=22$ & $\mathrm{n}=51$ & $\mathrm{n}=73$ & $\mathrm{n}=73$ \\
\hline $\mathrm{km}(\mathrm{m} *[\mathrm{IQR} * *])$ & $27[9-37]$ & $8[5-27]$ & $12[6-34]$ & $8[6-34]$ \\
\hline Co-working & $\mathrm{n}=44$ & $\mathrm{n}=5$ & $\mathrm{n}=49$ & $\mathrm{n}=49$ \\
\hline $\mathrm{km}(\mathrm{m}[\mathrm{IQR}])$ & $2[1-4]$ & $3[2-3]$ & $2[1-4]$ & $2[2-4]$ \\
\hline
\end{tabular}

$* \mathrm{~m}=$ median; $*$ IQR $=$ inter-quartile range; $* * \mathrm{CH}=$ Switzerland

by the commercial farm group (Table 3 ). Between farms sharing employees a median distance of $2 \mathrm{~km}$ was identified. Thus sharing employees happened within a neighbourhood and should not be classified as a remote contact.

\section{Poultry movements}

Poultry movements were identified for $65 \%$ of the participating farms, with $79 \%$ among commercial and $55 \%$ among non-commercial farms. Purchase of poultry occurred more often $(61 \%)$ than sale $(25 \%)$ and exhibiting birds at poultry shows $(3 \%)$, with a higher contribution of commercial farms except for poultry shows (Table 4).

Geo-mapping of the air-line distances showed a geographical overlap of all poultry movements by commercial and non-commercial farms in farm dense areas. Itemizing poultry movements by type of origin and destination contact revealed characteris- 
Table 4. Contact relations and median maximum distances to contact partners in $\mathrm{km}$ by the commercial and the non-commercial farm group and data extrapolation to the entire Swiss poultry sector.

\begin{tabular}{|c|c|c|c|c|}
\hline & Commercial & Non-commercial & All & $\begin{array}{l}\text { Extrapolation to } \\
\mathrm{CH}^{* * *} \text { poultry sector }\end{array}$ \\
\hline Purchase (total) & $\begin{array}{c}\mathrm{n}=534 \\
75 \%\end{array}$ & $\begin{array}{c}\mathrm{n}=783 \\
52 \%\end{array}$ & $\begin{array}{c}\mathrm{n}=1,317 \\
61 \%\end{array}$ & $\begin{array}{c}n=1,317 \\
50 \%\end{array}$ \\
\hline Sale (total) & $\begin{array}{c}\mathrm{n}=534 \\
50 \%\end{array}$ & $\begin{array}{c}\mathrm{n}=783 \\
8 \%\end{array}$ & $\begin{array}{c}\mathrm{n}=1,317 \\
25 \%\end{array}$ & $\begin{array}{c}\mathrm{n}=1,317 \\
8 \%\end{array}$ \\
\hline Poultry show (exhibiting birds) & $\begin{array}{c}\mathrm{n}=518 \\
2 \%\end{array}$ & $\begin{array}{c}\mathrm{n}=754 \\
4 \%\end{array}$ & $\begin{array}{c}\mathrm{n}=1,272 \\
3 \%\end{array}$ & $\begin{array}{c}\mathrm{n}=1,272 \\
3 \%\end{array}$ \\
\hline $\begin{array}{l}\text { Fraction of farms having one } \\
\text { or more of above incidents }\end{array}$ & $\begin{array}{c}\mathrm{n}=518 \\
79 \%\end{array}$ & $\begin{array}{c}\mathrm{n}=754 \\
55 \%\end{array}$ & $\begin{array}{c}\mathrm{n}=1,272 \\
65 \%\end{array}$ & $\begin{array}{c}\mathrm{n}=1,272 \\
52 \%\end{array}$ \\
\hline \multicolumn{5}{|l|}{ Distances } \\
\hline $\begin{array}{l}\text { Purchase of poultry (total) } \\
\mathrm{km}\left(\mathrm{m}^{*}\left[\mathrm{IQR}^{* *}\right]\right)\end{array}$ & $\begin{array}{c}\mathrm{n}=337 \\
40[23-74]\end{array}$ & $\begin{array}{c}\mathrm{n}=337 \\
16[8-29]\end{array}$ & $\begin{array}{c}\mathrm{n}=674 \\
25[12-51]\end{array}$ & $\begin{array}{c}\mathrm{n}=674 \\
16[8-32]\end{array}$ \\
\hline Purchase from hatchery & $\begin{array}{c}n=223 \\
37[23-74]\end{array}$ & $\begin{array}{c}\mathrm{n}=46 \\
23[13-37]\end{array}$ & $\begin{array}{c}n=269 \\
36[22-68]\end{array}$ & $\begin{array}{c}\mathrm{n}=269 \\
26[16-51]\end{array}$ \\
\hline Purchase from other farm & $\begin{array}{c}\mathrm{n}=134 \\
37[18-67]\end{array}$ & $\begin{array}{l}\mathrm{n}=311 \\
15[7-28]\end{array}$ & $\begin{array}{l}\mathrm{n}=445 \\
18[8-40]\end{array}$ & $\begin{array}{l}\mathrm{n}=445 \\
15[7-28]\end{array}$ \\
\hline $\begin{array}{l}\text { Sale of poultry (total) } \\
\mathrm{km}(\mathrm{m}[\mathrm{IQR}])\end{array}$ & $\begin{array}{c}n=148 \\
25[13-60]\end{array}$ & $\begin{array}{c}\mathrm{n}=40 \\
10[2-17]\end{array}$ & $\begin{array}{c}\mathrm{n}=188 \\
20[9-51]\end{array}$ & $\begin{array}{c}\mathrm{n}=188 \\
10[3-21]\end{array}$ \\
\hline Sale to hatchery & $\begin{array}{c}\mathrm{n}=6 \\
18[6-25]\end{array}$ & $\begin{array}{c}n=2 \\
9[7-12]\end{array}$ & $\begin{array}{c}\mathrm{n}=8 \\
12[6-24]\end{array}$ & $\begin{array}{c}\mathrm{n}=8 \\
12[7-12]\end{array}$ \\
\hline Sale to abattoir/butcher & $\begin{array}{c}\mathrm{n}=119 \\
31[15-72]\end{array}$ & $\begin{array}{c}\mathrm{n}=2 \\
18[15-21]\end{array}$ & $\begin{array}{c}\mathrm{n}=121 \\
30[15-71]\end{array}$ & $\begin{array}{c}\mathrm{n}=121 \\
29[15-64]\end{array}$ \\
\hline Sale to other farm & $\begin{array}{l}\mathrm{n}=27 \\
9[3-19]\end{array}$ & $\begin{array}{c}\mathrm{n}=38 \\
10[2-17]\end{array}$ & $\begin{array}{c}\mathrm{n}=65 \\
10[2-17]\end{array}$ & $\begin{array}{c}\mathrm{n}=65 \\
9[2-17]\end{array}$ \\
\hline $\begin{array}{l}\text { Poultry show (exhibiting birds) } \\
\mathrm{km}(\mathrm{m}[\mathrm{IQR}])\end{array}$ & $\begin{array}{c}\mathrm{n}=9 \\
28[16-44]\end{array}$ & $\begin{aligned} \mathrm{n} & =25 \\
27 & {[9-56] }\end{aligned}$ & $\begin{array}{c}\mathrm{n}=34 \\
28[12-48]\end{array}$ & $\begin{array}{c}\mathrm{n}=34 \\
18[9-45]\end{array}$ \\
\hline
\end{tabular}

$* \mathrm{~m}=$ median; **IQR = inter-quartile range; *** $\mathrm{CH}=$ Switzerland

tic patterns. Purchase from hatcheries (Fig. 3a) and sale to abattoirs/butchers (Fig. 3a) by commercial farms was focused. The foci were the same for farms integrated into the same company, confirmed by the interviewed experts. Commercial farms were not always affiliated to the company whose hatchery and abattoir were closest to the farm. Each of the companies had contract farms in up to 19 of the 26 Swiss cantons. That implies same suppliers, consulters and veterinarians serve contract farms over large parts of the country. Commercial farms' purchases from other farms were mainly identified as laying farms buying laying hens from growers. Noncommercial farms had essentially other farms as contact partners, clear centers in the overall pattern were not identified (Figs. 3a-6a).
The air-line distances of poultry purchase increased significantly with increasing farm size. For purchases from hatcheries, the increase was estimated as $0.75 \mathrm{~km}$ per farm size increase by 1000 birds $(\mathrm{P}=0.026)$ (Fig. 3b), for purchases from other farms the increase was $1.80 \mathrm{~km}(\mathrm{P}<0.001)$ (Fig. 4b). Sales to abattoirs/butchers $(\mathrm{P}=0.378)$, to other farms $(P=0.718)$, and distances to poultry shows where a farm's own birds were exhibited $(\mathrm{P}=0.582)$ did not depend on the farm size (Fig. 5b-7b).

Comparison of median distances between participant groups revealed poultry purchase $(25.1 \mathrm{~km}$ median distance) being more than twice as distant for commercial farms $(40 \mathrm{~km})$ than for non-commercials $(16 \mathrm{~km})$. Median poultry sale distances $(20 \mathrm{~km})$ were $25 \mathrm{~km}$ for commercial farms and $10 \mathrm{~km}$ for non-com- 

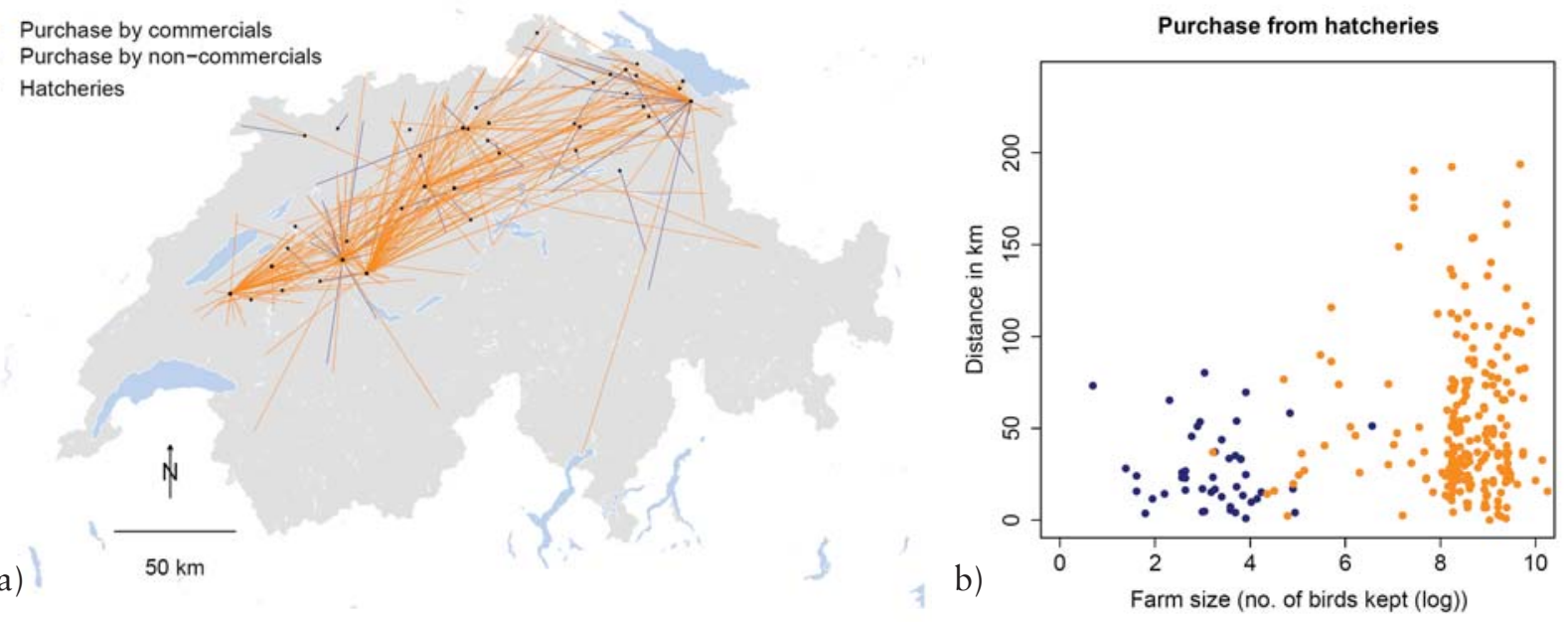

Fig. 3. Poultry movements. Map 3a indicates airline distances for purchase from hatcheries (black dots) by commercial (orange lines) and non-commercial farms (blue lines). In the scatter plot $3 \mathrm{~b}$ correlation between farm size (log) and airline distances is shown. Non-commercial farms are represented by blue dots, commercial farms by orange dots.
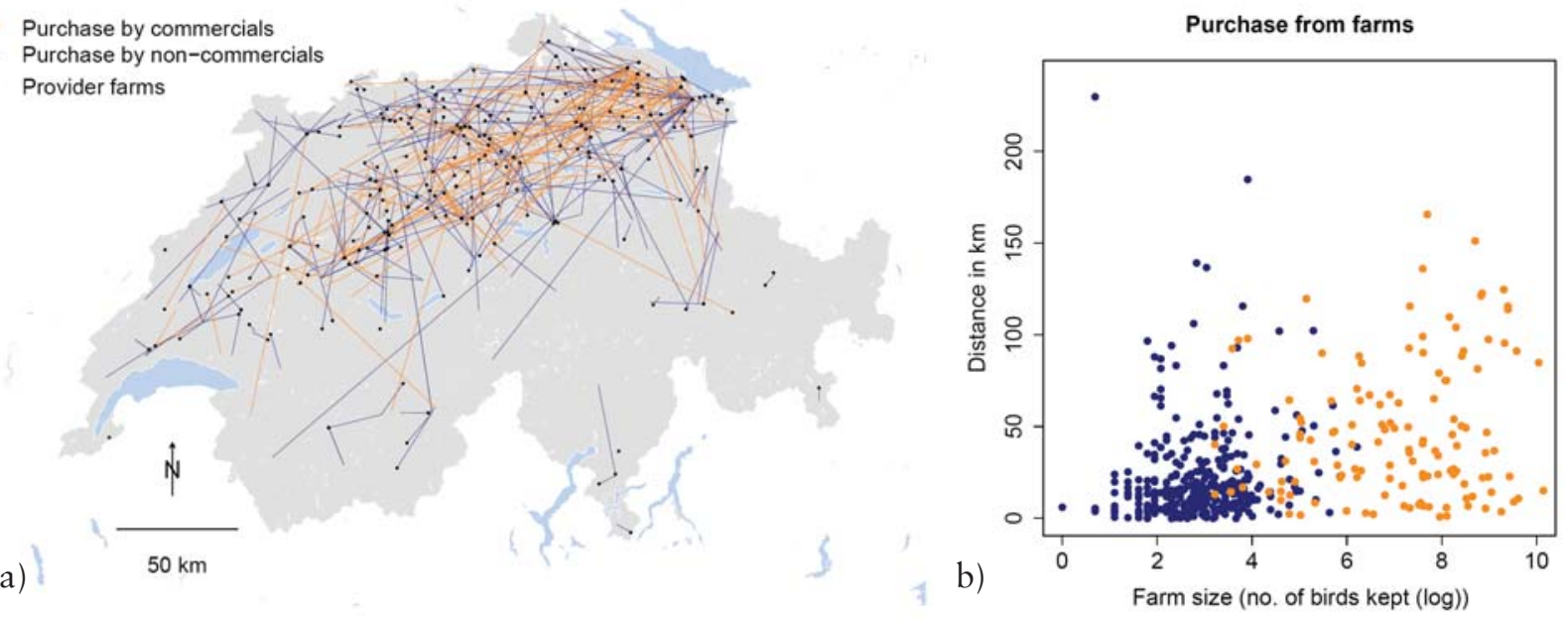

Fig. 4. Poultry movements. Map 4a indicates airline distances for purchase from other farms (black dots) by commercial (orange lines) and non-commercial farms (blue lines). In the scatter plot $4 \mathrm{~b}$ correlation between farm size (log) and airline distances is shown. Non-commercial farms are represented by blue dots, commercial farms by orange dots.

mercials, explained by the commercials' longer journeys to abattoirs $(31 \mathrm{~km})$. In contrast to distances for "poultry shows (visiting only)", distances to poultry shows where owned birds were exhibited were about equal for commercial (median distance of $28 \mathrm{~km}$ ) and non-commercial farms $(27 \mathrm{~km})$ (Table 4$)$. Within the non-commercial group show participation was mainly attributed to farms self-described as "show bird breeders" (odds ratio $(\mathrm{OR})=8.0 ; 95 \%$ confidence interval $(\mathrm{CI})=4.9-13.2, \mathrm{n}=783)$. Among the commercial farms, 6 out of 9 responses were attributable to self-described "layer farms". 



Fig. 5. Poultry movements. Map 5a indicates airline distances for sales to abattoirs or butchers (black dots) by commercial (orange lines) and non-commercial farms (blue lines). No significant correlation between farm size (log) and airline distances was found (scatter plot $5 \mathrm{~b}$ ). Non-commercial farms are represented by blue dots, commercial farms by orange dots.
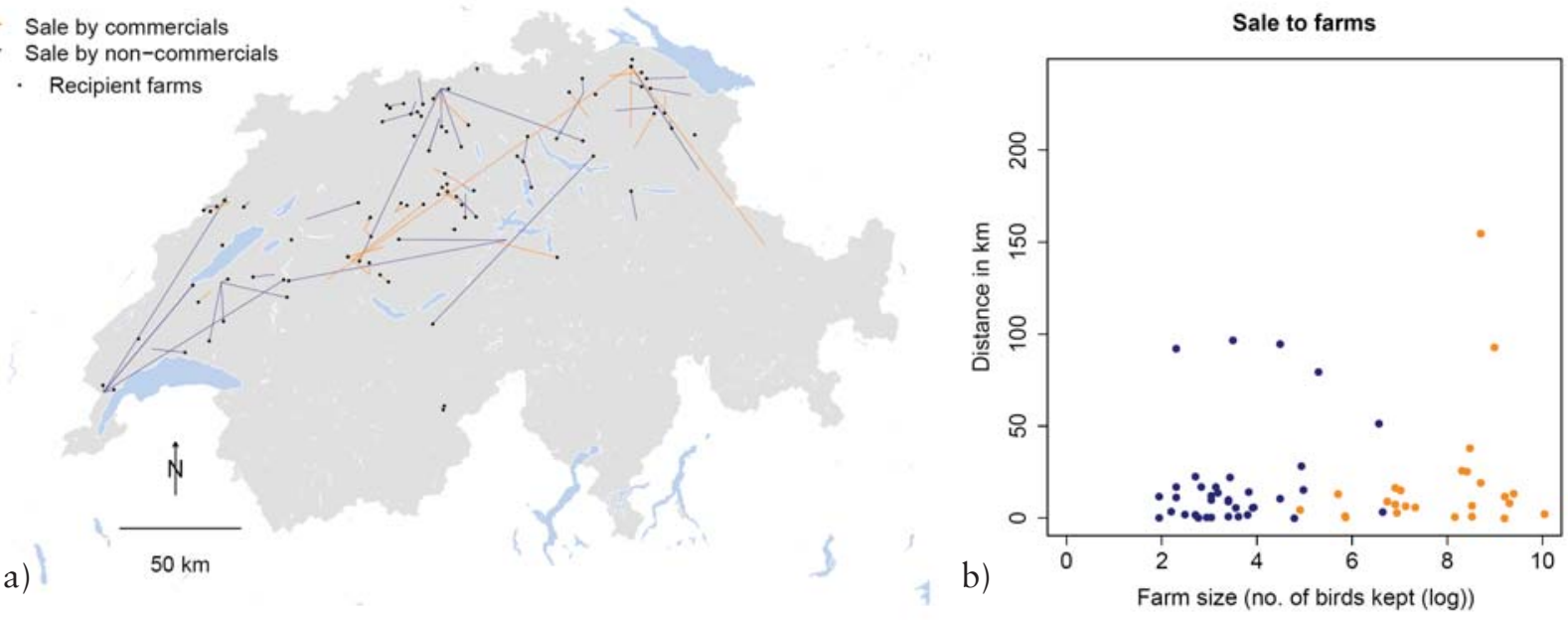

Fig. 6. Poultry movements. Map 6a indicates airline distances for sales to other farms (black dots) by commercial (orange lines) and non-commercial farms (blue lines). No significant correlation between farm size (log) and airline distances was found (scatter plot 6b). Non-commercial farms are represented by blue dots, commercial farms by orange dots.

\section{Poultry movements across the farm groups}

Commercial and non-commercial farms were directly connected by between-farm poultry movements. Out of a total of 767 specified purchases and sales between farms, $212(28 \%)$ contacts were within the commercial farm group only, and 198 $(26 \%)$ within the non-commercial farm group only. Across group contacts were mainly from commercial to non-commercial $(347 ; 45 \%)$ and 10 times (1\%) from non-commercial to commercial farm types. Commercial to non-commercial contacts 

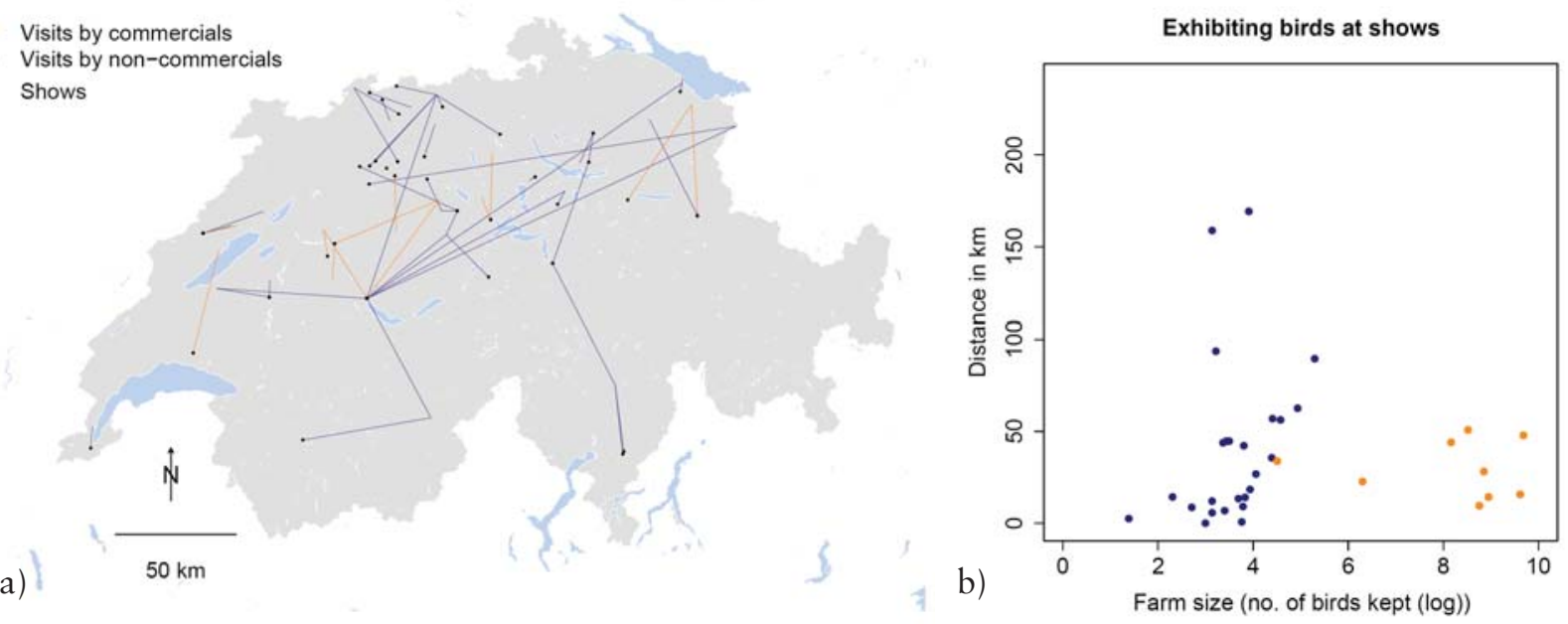

Fig. 7. Poultry movements. Map 7a indicates airline distances for poultry show visits where own birds were exhibited (black dots) by commercial (orange lines) and non-commercial farms (blue lines). No significant correlation between farm size (log) and airline distances was found (scatter plot $7 \mathrm{~b}$ ). Non-commercial farms are represented by blue dots, commercial farms by orange dots.

were mainly identified to be from grower and layer farms to backyard poultry farms. The experts from Companies III, IV and V confirmed that some grower farms produced an excess of laying hens knowing the market opportunity to supply noncommercial farmers. Several layer farms were known to sell their hens, sorted out after one year of production, at low price to non-commercial farmers rather than disposing of them or supplying them to soup-hen production. Non-commercial to commercial farm contacts were attributed to several commercial farms keeping small flocks in a hen house separate from the commercial production although this was not recommended by the companies.

Further connections were found through the access to the same hatcheries in 4 cases (Fig. 3a) and the same poultry shows in 2 cases (Fig. 7a) by both commercial and the non-commercial farms. The "use of dead stock collection point", the officially recommended practice for the disposal of dead livestock and pets, created a further link (although not through live poultry movement) as commercial and non-commercial farms share the same facilities.

\section{Number of different contact partners}

Only one contact partner per each origin (hatchery and other farm) and destination (hatchery, abattoir/butcher and other farm) contact relation was found in most cases. Exceptions were observed in the few specialized farms. Grower farms supplied up to hundreds of commercial layer farms with laying hens. The experts confirmed that this distribution of the number of contact partners (degree distribution) was highly skewed and that the contacts were mostly stable over time.

\section{Frequency of poultry movements}

Movement frequencies were higher at commercial farms compared to non-commercial farms. Higher figures for commercial farms were explained by 6 to 8 transactions a year at broiler farms for purchase and sale, one purchase and sale by layer farms, and up to 80 purchases per year and daily sales by the few specialized farms (parents or grower farms cf. box 1 , or farms having more than one production level). Non-commercial farms had purchases and sales one time or less per year. If owned birds were 
exhibited at poultry shows, this was commonly done twice a year for both commercial and noncommercial farms. Both groups had outliers with 20 to 30 show attendances per year.

Data extrapolation to the entire poultry sector in Switzerland

Contact data were collected on a sample where the poultry keepers' probability of being selected was proportional to farm size, to ensure a sufficient number of the less numerous larger poultry farms. To provide contact estimates for the entire poultry sector, contact data were extrapolated on the entire poultry sector taking the sampling weight into account. Except for contact relations uncommon among non-commercial farms (such as sales to abattoirs/butchers), the extrapolated values were in the same range as in the non-commercial farm group (right column of Tables 2-5).

Estimates of the median number of poultry movements per month in Switzerland were calculated, ignoring seasonal variations of layer farms. Accordingly, 488 (95\% CI = 443-538) purchases per month would be performed by farms with 500 or more birds kept (basically commercial farms), and $1686(95 \% \mathrm{CI}=1,665-1,707), 3.5(95 \% \mathrm{CI}=$ 3.1-3.9) times more, by farms smaller than 500 birds (basically non-commercial) farms. Poultry sales would be in the same range with 1092 (95\% CI $=880-1327)$ for large and 1018 (95\% CI = 925-1116) for small farms. Poultry movements to poultry shows would be $45(95 \% \mathrm{CI}=31-63)$ by large, and 655 (95\% CI = 624-687), 14.6 (95\% $\mathrm{CI}=9.9-22.2)$ times more transactions, by small farms.

\section{Discussion}

We aimed to identify between-farm contacts potentially allowing for HPAI to be spread between and amongst poultry farms in Switzerland. At the completion of this study, countrywide density maps for both poultry farms and birds kept were produced for the first time for Switzerland. Both density maps provided complementary information. Bird density is an import factor to assess infection pressure. Farm density is relevant to HPAI control measurements such as the implementation of control and surveillance zones around farms. When only commercial poultry farms are included in farm density maps it might be concluded that areas such as south of Bellinzona have a very low farm density and thus are of minor importance for HPAI surveillance. In fact, the area south of Bellinzona is the most dense for poultry farms in Switzerland with more than 8 poultry farms per $\mathrm{km}^{2}$ when non-commercial farms are included in the dataset.

Our findings support the concept of "farm neighbourhood" as a potential contact in poultry farm population models. The two participant groups, poultry keepers with commercial (large) and noncommercial (small) farms were found to have equal neighbourhood characteristics: (i) the number of other poultry farms in the neighbourhood, and (ii) the potential human and animal vectors such as cats

Table 5. Frequency of poultry movements in times per year by the commercial and non-commercial farm group and data extrapolation to the entire Swiss poultry sector.

\begin{tabular}{|c|c|c|c|c|}
\hline & Commercial & Non-commercial & All & $\begin{array}{l}\text { Extrapolation to } \\
\mathrm{CH}^{* * *} \text { poultry sector }\end{array}$ \\
\hline Purchase (total) & $\mathrm{n}=395$ & $\mathrm{n}=405$ & $\mathrm{n}=800$ & $\mathrm{n}=800$ \\
\hline times per year $(\mathrm{m} *[\mathrm{IQR} * *])$ & 5 [1-7] & $1[0.5-1]$ & $1[0.75-5]$ & $1[0.5-1]$ \\
\hline Sale (total) & $\mathrm{n}=262$ & $\mathrm{n}=62$ & $\mathrm{n}=324$ & $\mathrm{n}=324$ \\
\hline times per year (m [IQR]) & $6[2-7]$ & $1[0.5-2]$ & $6[2-7]$ & $2[0.5-3]$ \\
\hline Poultry show (exhibiting birds) & $\mathrm{n}=9$ & $\mathrm{n}=27$ & $\mathrm{n}=36$ & $\mathrm{n}=36$ \\
\hline times per year (m [IQR]) & $2[1-10]$ & $2[1-3]$ & $2[1-3]$ & $2[1-3]$ \\
\hline
\end{tabular}

$* \mathrm{~m}=$ median; $*$ IQR $=$ inter-quartile range; $* * \mathrm{CH}=$ Switzerland 
and small birds (unpublished data) present on the farms. Free-range systems, facilitating vectors' access to domestic poultry and thus the risk of HPAI virus dissemination, were more common among non-commercial farms (92\%) compared to commercial farms (61\%) (unpublished data). Sharing employees within a neighbourhood was, in contrast, more common among commercial $(10 \%)$ compared to non-commercial farms $(1 \%)$. This could increase the risk of HPAI virus dissemination amongst commercial farms, in the case where hygiene measurements are deficient.

The majority of farms were involved in human movements and shared resources $(78 \%)$ and/or poultry movements $(65 \%)$. The fraction was higher among commercial farms and distances were larger compared to non-commercial farms, except for those that exhibited birds at poultry shows. The number of different contact partners and poultry movement frequencies had skewed distributions. Few specialized grower and parent farms had high rates, mainly of outgoing contacts. The majority had low rates or no contacts at all. Highly connected farms are critical for a rapid spread of an epidemic (Bell et al., 1999). These farms must therefore be well surveyed by veterinary authorities. The operating companies and producer must be particular vigilant at maintaining good farm hygiene management practices.

Poultry movement frequencies were higher at commercial farms compared to non-commercial farms. Estimates however for the entire population of poultry farms revealed 3.5 times higher chances of a poultry purchase, and 14.6 times higher chances of exhibiting birds at poultry shows occurring in a given time by a farm smaller 500 than birds (non-commercial farm) than by a larger (commercial) farm. This is because $95 \%$ of poultry farms in Switzerland keep less than 500 birds.

The common assumption of a closed circuit of the commercial poultry production without connections to non-commercial farms does not entirely hold true. Commercial and non-commercial farms were functionally connected through direct purchase and sale interactions (mainly from commercial to noncommercial), access to the same dead stock collection points and hatcheries and visits of the same poultry shows.

The pattern of contacts between poultry farms has been investigated in terms of whether or not contact incidents were present. This was ignoring the strength of contacts (e.g. number of birds moved per transaction) and hygiene precautions taken by the poultry keepers. Contact partners were identified on a postal code level for data protection and the respondent's convenience resulting in only approximate air-line distances. Knowledge on effective transport routes may identify potential critical control points for remote contacts. We assume a slight under-reporting of contacts in the questionnaire: in follow-up interviews with 28 of the non-commercial respondents, it was sporadically explained that respondents had received birds as a gift that they had not declared in the postal questionnaire (Kernen, 2008). Interviews with experts from poultry industry indicated that commercial broiler producers do not always own the flock but raise birds on contract. This may explain why only $76.8 \%$ of the broiler subgroup indicated "purchase of poultry/hatching eggs".

There is a need to better understand why and under what conditions non-commercial keepers trade over long distances even though they have many other poultry farms in their direct neighbourhood. The identified structural properties of the poultry sector must be complemented with data of biological factors for sound predictions of outbreak dynamics. For instance, HPAI susceptibilities could be flock specific depending on virus strain and species kept, as described for the H7N7 outbreak in the Netherlands in 2003 (Stegeman et al., 2004).

Our findings have both local and global implications; for instance on zoning (geographical division) and compartmentalization (functional division by biosecurity measures). These are strategies introduced by the World Organization of Animal Health (OIE) to allow unaffected parts or segments of larger countries to continue trading during an epidemic 
(Bruschke and Vallat, 2008). Geographical and functional connections between commercial and non-commercial poultry farm subpopulations, as found in Switzerland, might also exist in larger countries. Geographical separations might be especially difficult to establish and maintain when poultry farm density is high over larger areas. Further, the present study helps to strengthen awareness for the importance of comprehensive and well organized epidemiological baseline data on the poultry population. The legislative basis for a mandatory notification of all poultry on a national level has been created in Switzerland (Schweizerischer Bundesrat, 2009). The future national poultry register would, ideally, be entirely geo-referenced, maintained in a relational database format, and linked up with data on poultry movements and data on presence of wild birds and waterfowl as main reservoirs. Regarding other livestock species, movement databases for cattle have shown to capture spatio-temporal data in nearly real-time (Robinson and Christley, 2006). Such data support authorities in the timely prevention, surveillance and control of HPAI and any other poultry epidemic or zoonotic disease. Maps are a well-proven utility for combined presentations of data on agricultural, wildlife and ecosystem factors in preventive (East et al., 2008a, b) and post-outbreak investigations concerning HPAI (Ward et al., 2008).

As for models for HPAI transmission, the study results indicate that contact patterns are far from random given close neighbourhood, farm type-specific long distance contacts and strong influence of the farms' affiliation to companies. To reflect the population's contact characteristics the combination of diffusion models (to reflect neighbourhood contacts) and network models (to reflect long distance poultry movement contacts) as suggested by Truscott et al. (2007) should be considered. However, this should not only be done for commercial farms but also for non-commercial farms.

Our findings indicate that both commercial and non-commercial farms are involved in neighbourhood and remote between-farm contacts relevant to
HPAI spread. It is necessary to include all poultry farms, irrespective of their size and purpose in both livestock registration and disease surveillance systems, as well as in transmission models for poultry and zoonotic diseases.

\section{Acknowledgements}

LF and JS were funded by the Swiss Federal Veterinary Office (project 1.07.05). LF, JS, JH and JZ were partly funded by the research project "Constanze" (project 1.07.01). TS was funded by the Swiss National Science Foundation (project 320030-114122). The authors thank Kay W. Axhausen and Veronika Killer from the Institute for Transport Planning and Systems of the ETH Zurich for providing geographical coordinates for all locations. We also thank Michael Binggeli and Heinz-Peter Schwermer from the Swiss Federal Veterinary Office for providing adapted Swisstopo base maps, and Tyler O'Neill for assistance with English editing. We acknowledge all study participants and interviewed experts for their valuable information and time. The authors declare that they have no competing interests.

\section{References}

Anderson RM, May RM, 1991. Infectious diseases of humans: dynamics and control. Oxford University Press, Oxford, UK.

Bansal S, Grenfell BT, Meyers LA, 2007. When individual behaviour matters: homogeneous and network models in epidemiology. J R Soc Interface 4, 879-891.

Bell DC, Atkinson JS, Carlson JW, 1999. Centrality measures for disease transmission networks. Soc Networks 21, 1-21. Boender GJ, Hagenaars TJ, Bouma A, Nodelijk G, Elbers AR, De Jong MC, van Boven M, 2007. Risk maps for the spread of highly pathogenic avian influenza in poultry. PLoS Comput Biol 3, e71.

Bruschke C, Vallat B, 2008. OIE standards and guidelines related to trade and poultry diseases. Rev Sci Tech 27, 627632.

Bundesamt für Landwirtschaft, 2007. Agrarinformationssystem AGIS (agrar information system). http://www.blw.admin. ch/themen/00006/00232/index.html?lang=de (accessed on 16 October 2009). 
Bundesversammlung der Schweizerischen Eidgenossenschaft, 2006. Tierseuchengesetz (TSG) vom 1. Juli 1966, Stand 13. Juni 2006 (Federal Parliament of Switzerland: Animal Health Act of 1st June 1966, as at 13 June 2006). http://www.admin.ch/ch/d/sr/c916_40.html (accessed on 4 June 2009).

Capua I, Dalla PM, Mutinelli F, Marangon S, Terregino C, 2002a. Newcastle disease outbreaks in Italy during 2000. Vet Rec 150, 565-568.

Capua I, Mutinelli F, Pozza MD, Donatelli I, Puzelli S, Cancellotti FM, 2002b. The 1999-2000 avian influenza (H7N1) epidemic in Italy: veterinary and human health implications. Acta Trop 83, 7-11.

de Jong JC, Claas EC, Osterhaus AD, Webster RG, Lim WL, 1997. A pandemic warning? Nature 389, 554.

DEFRA, 2007. Outbreak of highly pathogenic H5N1 avian influenza in Suffolk in January 2007. http://news.bbc.co.uk/2/shared/bsp/hi/pdfs/20_04_07_defra _bird.pdf (accessed on 20 June 2009).

Dent JE, Kao RR, Kiss IZ, Hyder K, Arnold M, 2008. Contact structures in the poultry industry in Great Britain: exploring transmission routes for a potential avian influenza virus epidemic. BMC Vet Res 4, 27.

Duerr HP, Schwehm M, Leary CC, de Vlas SJ, Eichner M, 2007. The impact of contact structure on infectious disease control: influenza and antiviral agents. Epidemiol Infect 135, 1124-1132.

East IJ, Hamilton SA, Garner G, 2008a. Identifying areas of Australia at risk of $\mathrm{H} 5 \mathrm{~N} 1$ avian influenza infection from exposure to migratory birds: a spatial analysis. Geospat Health 2, 203-213.

East IJ, Hamilton SA, Sharp LA, Garner MG, 2008b. Identifying areas of Australia at risk for $\mathrm{H} 5 \mathrm{~N} 1$ avian influenza infection from exposure to nomadic waterfowl moving throughout the Australo-Papuan region. Geospat Health 3, 17-27.

Fasina FO, Sirdar MM, Bisschop SP, 2008. The financial cost implications of the highly pathogenic notifiable avian influenza H5N1 in Nigeria. Onderstepoort J Vet Res 75, 39-46.

Garber L, Hill G, Rodriguez J, Gregory G, Voelker L, 2007. Non-commercial poultry industries: surveys of backyard and gamefowl breeder flocks in the United States. Prev Vet Med 80, 120-128.
Grabkowsky B, 2007. Wie sicher ist Ihr Betrieb vor der Geflügelpest? [Avian influenza: how safe is your farm?]. Institut für Strukturforschung in agrarischen Intensivgebieten http://www.animal-health-online.de/drms /gef/analyse_ispa.pdf (accessed on 4 June 2009).

Hauser R, Breidenbach E, Jost U, Bachmann I, 2006a. Risikobasierte Massnahmen beim Auftreten von HPAI H5N1 bei Wildvögeln - Präventive Massnahmen in Risikogebieten [Risk based measurements in the case of HPAI H5N1 at wild birds - preventive measurements in risk areas]. http://www.bvet.admin.ch/gesundheit_tiere/00315/00317/0 2600/index.html?lang=de (accessed on 4 June 2009).

Hauser R, Schwermer H, Breidenbach E, 2006b. Risikoabschätzung der Einschleppung von Aviärer Influenza in den Bestand der in Gefangenschaft gehaltenen Vögel der Schweiz [Risk assessment of avian influenza introduction into domestic poultry flocks in Switzerland]. http://www.bvet.admin.ch/gesundheit_tiere/00315/00317/0 2600/index.html?lang=de (accessed on 4 June 2009).

Hethcote HW, Yorke JA, 1984. Gonorrhea transmission dynamics and control. Springer, Berlin, Germany.

Hofmann MA, Renzullo S, Baumer A, 2008. Phylogenetic characterization of $\mathrm{H} 5 \mathrm{~N} 1$ highly pathogenic avian influenza viruses isolated in Switzerland in 2006. Virus Genes 37, 407-413.

Kernen T, 2008. Survey among Swiss poultry holders in the Lake of Constance region in relation to a potential spread of avian influenza. MSC thesis, University of Basel, Switzerland, pp. 23-30.

Kilpatrick AM, Chmura AA, Gibbons DW, Fleischer R, Marra PP, Daszak P, 2006. Predicting the global spread of H5N1 avian influenza. Proc Natl Acad Sci USA 103, 19368-19373.

Klopfleisch R, Wolf PU, Wolf C, Harder T, Starick E, Niebuhr M, Mettenleiter TC, Teifke JP, 2007. Encephalitis in a stone marten (Martes foina) after natural infection with highly pathogenic avian influenza virus subtype H5N1. J Comp Pathol 137, 155-159.

Koppinen J, 2005. How to finance animal health? Aust Vet J 83, 190.

Kuiken T, Rimmelzwaan G, van Riel D, van Amerongen G, Baars M, Fouchier R, Osterhaus A, 2004. Avian H5N1 influenza in cats. Science 306, 241.

Lyytikäinen T, Kallio ER, Sahlström L, Virtanen T, 2009. 
Consequences of networks in epidemiological predictions of FMD. In: Society for veterinary epidemiology and preventive medicine (SVEPM) proceedings 2009. Peeler EJ, Alban L, Russell A, and the SVEPM Executive Committee (Eds), London, UK, pp. 254-266.

Mayring P, 2003. Qualitative Inhaltsanalyse - Grundlagen und Techniken [Qualitative content analysis - basics and techniques]. Beltz UTB, Weinheim.

Normile D, 2005. Avian influenza. Are wild birds to blame? Science 310, 426-428.

OIE, 2002. Highly pathogenic avian influenza. Animal disease data http://www.oie.int/eng/maladies/fiches/a_A150.htm (accessed on 20 June 2009).

Pastor-Satorras R, Vespignani A, 2001. Epidemic spreading in scale-free networks. Phys Rev Lett 86, 3200-3203.

Reed KD, Meece JK, Henkel JS, Shukla SK, 2003. Birds, migration and emerging zoonoses: west nile virus, lyme disease, influenza A and enteropathogens. Clin Med Res 1, 5-12.

Robinson SE, Christley RM, 2006. Identifying temporal variation in reported births, deaths and movements of cattle in Britain. BMC Vet Res 2, 11.

Saurina J, Fiebig L, Zinsstag J, Schelling E, 2009. Disease awareness of the poultry keepers in Switzerland and their access to information concerning highly pathogenic avian influenza. Schw Arch Tierheilkd, in press.

Schweizerischer Bundesrat, 2005. Verordnung über vorsorgliche Sofortmassnahmen zur Verhinderung der Einschleppung der Klassischen Geflügelpest vom 21. Oktober 2005 [Federal Council of Switzerland: Regulation about the immediate precautionary measures for the prevention of introcution of highly pathogenic avian influenza from the 21st October 2005]. www.iffwil.ch/pdf/dl. php?pdf=Vogelgrippe_Verordnung.pdf (accessed on 30 August 2009).

Schweizerischer Bundesrat, 2009. Obligatorische Registrierung aller Pferde-, Fisch-, Bienen- und Geflügelhaltungen [Federal Council of Switzerland: Mandatory registration of all horse, fish, bee, and poultry keeping]. http://www.news.admin.ch/message/?lang=de\& msg-id=28490 (accessed on 10 September 2009).

Shirley MDF, Rushton SP, 2005. The impacts of network topology on disease spread. Ecol Complexity 2, 287-299. Smieszek T, Fiebig L, Scholz RW, 2009. Models of epidemics: when contact repetition and clustering should be included. Theor Biol Med Model 6, 11.

Stegeman A, Bouma A, Elbers ARW, de Jong MCM, Nodelijk G, de Klerk F, Koch G, van Boven M, 2004. Avian influenza A virus (H7N7) epidemic in the Netherlands in 2003: Course of the epidemic and effectiveness of control measures. J Infect Dis 190, 2088-2095.

Thomas ME, Bouma A, Ekker HM, Fonken AJ, Stegeman JA, Nielen M, 2005. Risk factors for the introduction of high pathogenicity avian influenza virus into poultry farms during the epidemic in the Netherlands in 2003. Prev Vet Med 69, 1-11.

Truscott J, Garske T, Chis-Ster I, Guitian J, Pfeiffer D, Snow L, Wilesmith J, Ferguson NM, Ghani AC, 2007. Control of a highly pathogenic H5N1 avian influenza outbreak in the GB poultry flock. Proc Biol Sci 274, 2287-2295.

Ward MP, Maftei D, Apostu C, Suru A, 2008. Geostatistical visualisation and spatial statistics for evaluation of the dispersion of epidemic highly pathogenic avian influenza subtype H5N1. Vet Res 39, 22.

Webster RG, Peiris M, Chen HL, Guan Y, 2006. H5N1 outbreaks and enzootic influenza. Emerg Inf Dis 12, 3-8.

WHO, 2006. Influenza research at the human and animal interface. WHO Working Group on influenza research, epidemic and pandemic alert and response WHO/CDS/EPR/GIP/2006.3.

WHO, 2009. Cumulative number of confirmed human cases of avian influenza $\mathrm{A} /(\mathrm{H} 5 \mathrm{~N} 1)$ reported to WHO. http://www.who.int/csr/disease/avian_influenza/country/cas es_table_2009_08_11/en/index.html (accessed on 30 August 2009).

Woolhouse ME, Dye C, Etard JF, Smith T, Charlwood JD, Garnett GP, Hagan P, Hii JL, Ndhlovu PD, Quinnell RJ, Watts CH, Chandiwana SK, Anderson RM, 1997. Heterogeneities in the transmission of infectious agents: implications for the design of control programs. Proc Natl Acad Sci USA 94, 338-342.

Zaric GS, 2002. Random vs. nonrandom mixing in network epidemic models. Health Care Manag Sci 5, 147-155. 